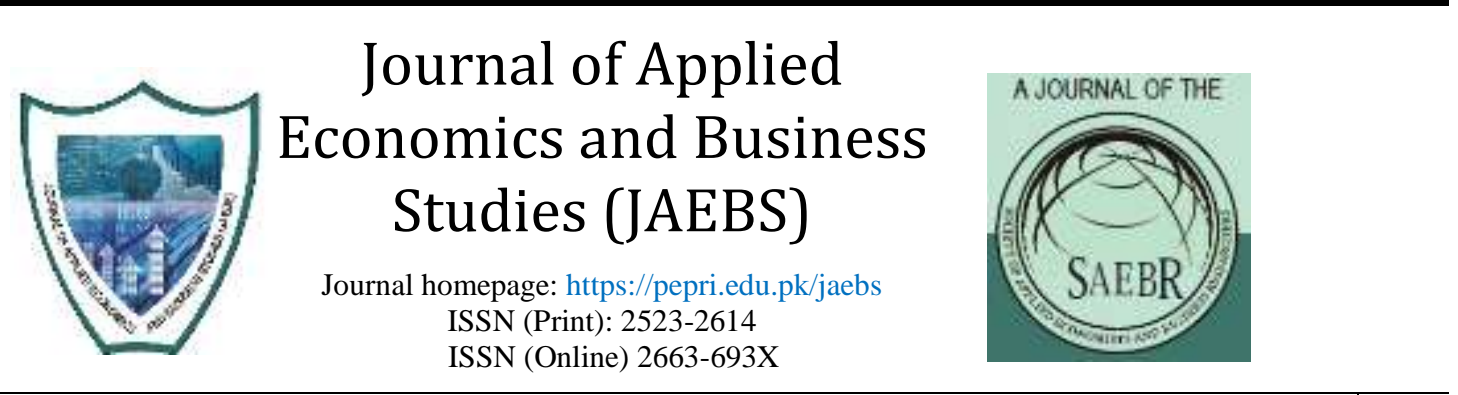

\title{
Food Security Assessment in Azad Jammu and Kashmir: Empirical Analysis of Dietary Diversity, Current and Project Food Demand and Supply-Demand Gap
}

\author{
Ghulam Sadiq Afridi ${ }^{1 *}$, Muhammad Ishaq ${ }^{2 * *} \&$ Abdul $\mathrm{Jabbar}^{3}$ \\ ${ }^{1}$ Principal Scientific Officer Social Sciences Division Pakistan Agricultural Research Council Islamabad-Pakistan \\ ${ }^{2}$ Director Agricultural Marketing and Trade Social Sciences Division, Pakistan Agricultural Research Council Islamabad-Pakistan \\ ${ }^{3}$ Assistant Professor, International Institute of Islamic Economic International Islamic University Islamabad-Pakistan.
}

\begin{abstract}
This study attempts to determine the dietary diversity score for different food groups and estimates the current demand for different food groups in AJK. Data for this study was collected from 1250 households covering all 10 administrative districts of AJK by following multi-stage sampling techniques through a comprehensive interview schedule. Ten commodity groups (Wheat, Rice, Milk, Meat, Vegetables, Fruits, Pulses, Oil/Ghee, Tea and Other food were developed for analysis. Linear Approximate-Almost Ideal Demand System (LA-AIDS) model was used for estimating food demand elasticities through Zellner's Seemingly Unrelated Regression by using STATA software. All the 10 food groups were found normal goods, except milk and fruits (income elasticity higher than unity). This implies that in future demand for milk and fruits would increase more proportionately as income would increase. The own price elasticities of all 10food groups were also found congruent to economic theory (Wheat-0.28, Rice0.65, Milk-0.92, Meat-0.34, Fruits-0.61, Vegetables-0.21, Pulses-0.29, Oil and ghee-0.04, Tea-0.35 and Other food-0.32). The income and own price elasticities depicted that wheat, vegetables, pulses and oil and ghee are necessities as compared to other food groups. The cross-price elasticity illustrated that rice could be a substitute for wheat and wheat for rice in the State of AJK. The Berry's Index (82.43) depicted that food was diverse on average with a minimum Index value of 61.31. The study of different factors in relation to Berry's Index depicted that education and income significantly and positively affect Berry's Index while location of household in urban or rural area do not affect diversification of food. Inclusion of all necessities in Food Stamp program and Ramadan package and efforts by agriculture and livestock department regarding improved production of food commodities are recommended.
\end{abstract}

Keywords

Dietary

Diversity, Food

Demand,

Supply-Demand Gap, LA-AIDS, AJK

JEL

Classification C3, C31, D01, D11, D12

\footnotetext{
* sadiqafridi@gmail.com

** ishaqecon@gmail.com
} 


\section{Introduction}

According to UNICEF-MICS survey about 28 percent children were underweight and 37 percent children were stunted in Azad Jammu and Kashmir due to nutritional status (UNICEF 2008). Consumption diversification is a widely used indicator especially in developing countries to capture various health indicators like, child underweight, stunting, infant mortality rate or improved birth rate, and also as an indicator in reduction of other child diseases.

Higher living standard of the household and balanced diet is indicated by Diversity in Food Consumption. Similarly, balanced life is signified by consumption expenditures on the non-food items including electricity, clothing, furniture, housing, transport and education; etc. Therefore, analysis of consumption patterns provides an insight into the status of human resource of the country.

Empirical research on food consumption patterns can provide evidence on consumers' responsiveness to price and expenditure changes that are useful in designing a country's food policies. Estimates of price and income elasticities of different foods play key role and not only help in setting administered prices but also help in designing policies regarding subsidy and tax policies. These policies also have great impact on poverty and food security. To formulate a long-term policy for food security and poverty reduction in a developing country, there is a need to understand how different groups of households respond to changes in the prices of different foods commodities. Ali and Farooq (2004) have found that "dietary diversity improves nutritional balance of the diet, which enhances productivity through possible improvement in health".

AJK is food deficit state in respect of production of cereals (wheat and rice), and fruit and vegetables. So far, no in-depth study has been carried out regarding production or consumption diversification at the state level. This study has been conducted in the State of AJK with objectives to examine and estimate the dietary/consumption diversification and dietary diversification score for different food groups at the State level; and to estimate current demand for different food groups in the State of AJK.

This research study was the ever firs attempt to analyze household food demand as no study prior to this could be found in this neglected area. Numerous research studies could be found of similar nature but all have been conducted in Pakistan mostly using HIES data set. Like Haq et al., (2011) examined household food demand pattern in Punjab Pakistan using HIES data by employing flexible LA-AIDS model both for rural and urban areas for wheat, rice, fruits, vegetables, milk, cooking oil, meat, and other food products. They found that households in both rural and urban areas with head of 
Journal of Applied Economics and Business Studies, Volume.4, Issue 3 (2020) 185-198 https://doi.org/10.34260/jaebs.438 family having agriculture as profession consume less of all foods with the exception of wheat. Households in both rural and urban areas with literate head of family consume more of all food products with the exception of vegetables and wheat. They further investigated that demand for all eight-food groups was price inelastic with wheat having the most price inelastic demand. All of the expenditure elasticities were positive suggested that all goods are normal with the largest expenditure elasticities found for milk followed by fruits, other food products, meat, rice, vegetables, wheat and cooking oil. Similarly, Ahmad et al., (2012) analyzed food consumption pattern of Pakistan at various income levels of the consumers at national as well as provincial levels by using Household Integrated Economic Survey (HIES), 1998-99 data.

\section{Methods}

\subsection{Universe and Sample Size}

This study was aimed to estimate dietary diversity, current food demand for AJK, therefore consideration in heterogeneity in consumption pattern was kept in mind and project area was split in two different strata, i.e., Northern AJK and Southern AJK, as there is substantial difference in the consumption pattern between the two strata. Northern AJK, comprised of Neelum, Muzaffaabad, Hatian, Bagh, Haveli, Sadhnoti and Poonch districts, is considered as rice consuming districts and Southern AJK, comprised of Kotli, Bhimber and Mirpur is considered as wheat consuming districts. For this purpose, district Neelum, Muzaffarabad and Poonch were selected from Northern AJK while district Kotli and Mirpur were selected from Southern AJK. District selection within strata was mainly based on income differences and/or development indicators. Through multi-stage sampling techniques, a sample of 1250 households was selected with representative sample from each district as per population of the respective district. Within district village and household selection was totally random. This study was conducted under "Research for Agricultural Development Research" in the year 201819.

\subsection{Food Groups}

Food items for in the analysis included i) wheat and wheat flour, ii) rice, iii) pulses, iv) fruits, v) vegetables, vi) milk and milk products, vii) meat, viii) tea and beverages, ix) oil and ghee, and $\mathrm{x}$ ) other food.

A single utility function for all the households was assumed to estimate the expenditure elasticities within all income level, and that preference ordering does not change across families. It was also assumed that for every commodity all the households 
face the same prices. The last assumption in this regard is that expenditures were used as proxy for income.

The Household Dietary Diversity Score (HDDS) was calculated according to the frequency of all above mentioned food groups. Besides HDDS, Berry's Index (Berry, 1970) was estimated as following;

$$
B I_{j}=1-\sum_{i=1}^{N} w_{i j}^{2}
$$

Where $w_{i j}$ is the expenditure share of food commodity $\mathrm{i}$ consumed by household $\mathrm{j}$. $\mathrm{N}$ is the total number of food items. The index was different from household to household and from rural to urban. The factors responsible for these differences were captured through the following model.

$$
B I_{j}=\alpha+\beta_{1} X_{1 j}+\beta_{2} X_{2 j} \ldots+\beta_{k} X_{k j}+\epsilon_{j}
$$

Where $\alpha$ and $\beta_{1}$ to $\beta_{\mathrm{k}}$ are the parameters to be estimated, $\mathrm{X}_{1}$ to $\mathrm{X}_{\mathrm{k}}$ are the explanatory variables while $\varepsilon_{\mathrm{j}}$ is the error term assumed to be normally distributed with zero mean and constant variance.

To estimate the elasticities of different food groups the following linear approximate almost ideal demand system (LA-AIDS) was employed developed by (Deaton and Muellbauer (1980).

$$
W_{i}=\alpha_{i}+\sum_{j} \gamma_{i j} \ln P_{j}+\beta_{i} \ln \left(x / P^{*}\right)+\phi z
$$

Where $\alpha_{i}, \beta_{i}, \gamma_{i j}$ are the parameters to be estimated, $w_{i}$ is budget share of $\operatorname{good} i$ ( $i$ $=1,2, \ldots, n), P_{j}$ is price of $\operatorname{good} j(j=1,2, \ldots, n)$ and $x$ is total expenditure and $P^{*}$ is Stone's price index:

$\ln P^{*}=\Sigma_{j} w_{j} \ln p_{j}$

This is the socioeconomics flexible Linear Approximate (LA) version of AIDS and it has been used extensively in consumer analysis, and the elasticities estimated using LA-AIDS are generally similar to those estimated using AIDS.

Expenditure Elasticity:

$$
\eta_{i}=\frac{\beta_{i}}{\omega_{i}}+
$$

Marshalian own and cross price elasticity for good i with respect to good $\mathrm{j}$ :

$$
\varepsilon_{i j}=\frac{\gamma_{i j}-\beta_{i} \omega_{j}}{\omega_{i}}-\delta_{i j}
$$

Hecksian own and cross price elasticity for good i with respect to good j:

$$
\mathfrak{e}_{i j}=\frac{\gamma_{i j}}{\omega_{i}}+\omega_{j}-\delta_{i j}
$$


Where $\delta_{\mathrm{ij}}$ is the Kronecker delta and equals 1 for own price and 0 for cross-price elasticities.

Projected demand for different food groups was estimated using following formulae.

$$
D_{t}=d_{0} \times N_{t}(1+y \times e)^{t}
$$

Where $D_{t}$ is household demand (million metric tonnes) of a commodity group in year $t, d_{0}$ is per capita consumption $(\mathrm{kg})$ of the commodity group in base year i.e. the year 2017, $N_{t}$ is the projected population (million) in the year $t, y$ is the growth in per capita income (GDP), $e$ is expenditure/income elasticity of demand for the commodity group, and $t$ represents years $1,2,3 \ldots \ldots .$. . for base year $t=0$.

$$
\text { Pop }_{\text {future }}=\text { Pop }_{\text {present }} \times(1+i)^{n}
$$

Where Pop future is the future population, Pop present is the present population $i$ is population growth rate and $n$ is number of year

\section{Results And Discussion}

Table-1 divulges the descriptive statistics of the sampled respondents. According to the table on average about $85 \mathrm{Kgs}$ of wheat and wheat flour, about $16 \mathrm{Kgs}$ of rice, 90 liters of milk and milk products, about $13 \mathrm{Kgs}$ of meat, $43 \mathrm{kgs}$ of vegetables, $64 \mathrm{kgs}$ of fruits, about $8 \mathrm{kgs}$ of pulses, $11 \mathrm{kgs}$ of oil and ghee, $2 \mathrm{kgs}$ of tea and about $4 \mathrm{kgs}$ of other food was consumed per capita per annum in AJK. The average household size was found to be 6 persons per household with minimum of 2 persons and maximum of 14 persons. Comparing these estimated statistics for AJK with Pakistan, it is evident that per capita wheat consumption is lower in AJK as compared to Pakistan (92 kgs), but consume more rice than Pakistan on average.

Table-1: Per Capita per Annum Consumption of Different Food Groups in AJK

\begin{tabular}{lrrr}
\hline Variables & Mean & Minimum & Maximum \\
\hline Wheat and Wheat Flour & 84.63 & 30.00 & 170.31 \\
Rice & 15.53 & 01.50 & 75.23 \\
Milk and Milk Products & 90.16 & 04.80 & 112.15 \\
Meat & 12.63 & 01.33 & 29.07 \\
Fruits & 43.27 & 03.43 & 114.11 \\
Vegetables & 64.04 & 07.20 & 122.38 \\
Pulses & 08.39 & 00.75 & 18.57 \\
Ghee and Oil & 11.03 & 20.40 & 28.71 \\
Tea (Green and Black) & 02.31 & 00.25 & 6.19 \\
Other Foods & 04.00 & 01.50 & 10.32 \\
Size of Household & 06.00 & 02.00 & 14.17 \\
\hline
\end{tabular}

Source: Author's own calculation based on Primary Data for the year 2017-18. 


\subsection{Results of the Berry's Index}

Results of the Dietary Index (Berry's Index) are depicted in Table 2. The dietary diversity score on average (82.32) revealed that diet is diversified on average with a little bit but not significant variation across region and districts. The results further divulged that income level and education affect diversification positively except family size. Food diversity is adversely affected by family size means that as family size increases food diversity decreases or people with large family size restricted to specialized food groups. This revealed that people having large family size could not afford diversified food.

Table-2: Results of the Berry's Index

\begin{tabular}{lrrr}
\hline Dep. Var $(\mathrm{BI})=82.32$ & Coefficient & St. error & t-value \\
\hline Constant & 0.797 & 0.010 & 81.64 \\
Family Size & -0.003 & 0.001 & $-4.451^{*}$ \\
Education & 0.732 & 0.371 & $1.973^{*}$ \\
Region (Rural/Urban) & 0.003 & 0.001 & 1.55 \\
Income & 0.004 & 0.002 & $2.003^{*}$ \\
\hline
\end{tabular}

Source: Author's own calculation based on Primary Data for the year 2018-19.

* show estimates are statistically significant at $5 \%$ level of significance.

\subsection{Income and Price Elasticities}

Estimates of the LA-AIDS model, income elasticities own price elasticities (Marshallian and Hicksian), cross price elasticities (Marshallian and Hicksian) for AJK have been given in the following Table- 3 to Table- 6 . All the 10 food groups were found normal goods having positive income elasticity (wheat- 0.33 , rice- 0.57 , milk- 1.37 , meat0.78 , fruits-1.45, vegetables-0.89, pulses- 0.11 , oil and ghee- 0.66 , tea- 0.40 and other food-0.87), however, milk and fruits were found to be luxurious as divulged by their income elasticities higher than unity. This means that in future demand for milk and fruits would increase more proportionately as income would increase. The own price elasticities of all 10-food groups were also found congruent to economic theory means were negative [wheat $(-0.28)$, rice $(-0.65)$, milk $(-0.92)$, meat $(-0.34)$, fruits, $(-0.61)$, vegetables $(-0.21)$, pulses $(-0.29)$, oil and ghee $(-0.04)$, tea $(-0.35)$ and other food ($0.32)]$. The income and own price elasticities depicted that wheat, vegetables, pulses and oil and ghee are highly necessities as compared to other food groups. The crossprice elasticity illustrated that rice could be used as substitute of wheat and wheat of rice in the State of AJK. Similarly, other food groups exhibit substitution and or complementary effect for one another. Our results are in line with the findings of Naveed et.al., (2016), Ahsan et.al., (2011), Haq et.al., (2011), and Farooq et.al., (1999). 190 
Journal of Applied Economics and Business Studies, Volume.4, Issue 3 (2020) 185-198 https://doi.org/10.34260/jaebs.438

Naveed et.al., (2016) found that food grains, pulses, ghee, sugar and vegetables are necessities, while milk and meat are luxuries. Pulses and vegetables, ghee and meat, milk and sugar are identified as gross complements on the basis of uncompensated cross-price elasticities. Similarly, Ahsan et.al., (2011) found that that supply- side factors (subsidies and world food prices) have a significant impact on food prices, whereas demand-side factors, such as money supply, are the main cause of the increase in food prices in the short as well as the long run.

Table-3: Expenditure Elasticities for Various Food Groups (AJK)

\begin{tabular}{lr}
\hline Food groups & Expenditure elasticities \\
\hline Wheat and Wheat Flour & $0.33(0.051)^{*}$ \\
Rice & $0.57(0.089)^{*}$ \\
Milk & $1.37(0.048)^{*}$ \\
Meat & $0.78(0.056)^{*}$ \\
Fruits & $1.45(0.066)^{*}$ \\
Vegetables & $0.89(0.049)^{*}$ \\
Pulses & $0.11(0.061)$ \\
Oil/Ghee & $0.66(0.052)^{*}$ \\
Tea & $0.40(0.062)^{*}$ \\
Other food & $0.87(0.066)^{*}$ \\
\hline
\end{tabular}

Source: Author's own calculation based on Primary Data for the year 2018-19.

* show estimates are statistically significant at $5 \%$ level of significance.

\subsection{Current and Projected Demand}

Estimates of the current and projected demand for various food groups have been presented in Table-7 and Table- 8 . The estimates of projected demand for the State of AJK in the year 2017 to 2050 depicted that wheat and wheat flour for the year 2017 was found to be 0.343 million tons while it would be $0.400,0.485,0.858$ and 1.255 million tons in the year 2020, 2025, 2040 and 2050 respectively. The current and projected demand for meat was found to be 0.051 million tons in 2017 and $0.068,0.129,0.244$ and 0.462 million tons in 2020,2030, 2040 and 2050 respectively. The current and projected demand for milk was found to be 365 million liters, 1426 million liters, 3777 million liters and 10006 million liters in the year 2017, 2020, 2030, 2040 and 2050 respectively. While calculating the supply and demand gap for major food groups, it was found that the State of AJK is deficit in wheat and wheat flour by 0.194 million tones currently while this gap would be more widened by the year 2025 at 0.306 million tons and 0.939 million tons by 2050. Similarly, the supply and demand gap for rice was found to be 0.056 million tons while this gap would be increased at 0.102 million tons in 2040 and at 0.169 million tons in 2050. The state of AJK was found surplus in Milk 
and Meat production but it would in the year 2030 AJK would be deficit in both these food groups at figures of 214 million liters of milk and 0.029 million tons of meat. The State of AJK was also found deficit in fruits and vegetables currently but after 2030 gap in demand and supply would be turned deficit.

\section{Conclusions and Recommendations}

Nonetheless the State of AJK is deficit in food production but still people of the State have diverse food. Based on the findings of the study it was suggested that agriculture department might suggest subsidized prices for necessities like wheat, pulses and vegetables especially in the month of Ramadan. All necessities food items might be included in Food Stamp Program for poor from the government side. Agriculture and livestock departments might align their plans and policies in accordance with the increased demand for food with growing population in future. If legislation is not possible at least efforts might be focused for crops enterprise selection in Northern and Southern parts of the State.

\section{References}

Ahmad, N., A. Raza and A. Saleem, (2012). "Food consumption analysis in: expenditure elasticities approach using HIES data". Interdisciplinary Journal of Contemporary Research in Business. Vol. 4 (4), 466 - 475. Retrieved from https://journals.sagepub.com/doi/abs/10.1177/1391561415621826

Ahsan, H, I. Zainab and M. K. Ali, (2011). The Determinants of Food Prices. PIDE Working Papers 2011:76. Retrieved from pide.org.pk/pdf/Working\%20Paper/WorkingPaper-76.pdf

Ali M. and U. Farooq (2004). Dietary Diversity and rural labor productivity: Evidence from Pakistan. Selected Long Paper (116971) prepared for presentation at the American Agricultural Economics Association Annual Meeting, Denver, Colorado, July 1-4, 2004. https://ageconsearch.umn.edu/record/20310/files/sp04al09.pdf

Berry, C. H., (1971). Corporate growth and diversification. Journal of Law and Economics Vol. 14, 371-383. Retrieved from https://econpapers.repec.org/RePEc:ucp:jlawec:v:14:y:1971:i:2:p:371-84

Burney, N. and M. Akmal, (1991). "Food Demand in Pakistan: An Application of Extended Linear Expenditure system" Journal of Agricultural Economics. Vol. 42, No 2, pp185-195.

Burney, N. and A.H. Khan, (1991). "Household Consumption Patterns in Pakistan: An Urban Rural Comparison using Micro Data" Pakistan Development Review, Vol.30, No.2, pp 145-171. 
Journal of Applied Economics and Business Studies, Volume.4, Issue 3 (2020) 185-198 https://doi.org/10.34260/jaebs.438

Deaton, A. and L. Muellbauer, (1980). An Almost Ideal Demand System. Amer. Econ. Rev. 70:312-26

Farooq, U., T. Young, and M. Iqbal. 1999. An Investigation into the Farm Households Consumption Patterns in Punjab, Pakistan. The Pakistan Development Review. 38:293-305

Haq, U. Z,. H. Nazli, K. Meilke, M. Ishaq, A. Khattak, A. H. Hashmi and F. U .Rehman. (2011). Food demand patterns in Pakistani Punjab. Sarhad Journal of Agriculture. Vol. 27 (2) 305-311. Retrieved from https://www.aup.edu.pk/.../24FOOD\%20DEMAND\%20PATTERNS\%20IN\%20PAKI

Naveed, H., A. Hussain and H. Yousaf, (2016). Food Demand in Pakistan- Analysis and Projection. South Asia Economic Journal. Vol. 17, (1), 94-113. https://doi.org/10.1177/1391561415621826 
Ghulam Sadiq Afridi, Muhammad Ishaq \& Abdul Jabbar

\begin{tabular}{|c|c|c|c|c|c|c|c|c|c|c|}
\hline Explanatory Variable & Wheat & Rice & Milk & Meat & Fruits & Vegetable & Pulses & Oil/Ghee & Tea & Other Food \\
\hline Log of Price of Wheat & $\begin{array}{l}0.058^{*} \\
(0.008)\end{array}$ & $\begin{array}{c}-0.020 * \\
(0.006)\end{array}$ & $\begin{array}{r}-0.029 * * * \\
(0.015)\end{array}$ & $\begin{array}{c}-0.024 * \\
(0.005)\end{array}$ & $\begin{array}{r}-0.026^{* *} * \\
(0.012)\end{array}$ & $\begin{array}{c}-0.008 \\
(0.006)\end{array}$ & $\begin{array}{r}-0.016^{* * *} \\
(0.009)\end{array}$ & $\begin{array}{r}0.002 \\
(0.004)\end{array}$ & $\begin{array}{l}0.013^{*} \\
(0.005)\end{array}$ & $\begin{array}{r}0.009 \\
(0.006)\end{array}$ \\
\hline Log of Price of Rice & $\begin{array}{c}-0.020^{*} \\
(0.006)\end{array}$ & $\begin{array}{l}0.018^{*} \\
(0.005)\end{array}$ & $\begin{array}{r}0.023^{* *} \\
(0.010)\end{array}$ & $\begin{array}{r}-0.009^{*} \\
(0.004)\end{array}$ & $\begin{array}{r}0.005 \\
(0.004)\end{array}$ & $\begin{array}{r}-0.015^{*} \\
(0.005)\end{array}$ & $\begin{array}{r}0.005^{* *} \\
(0.002)\end{array}$ & $\begin{array}{r}-0.010^{*} \\
(0.003)\end{array}$ & $\begin{array}{r}0.002 \\
(0.003)\end{array}$ & $\begin{array}{l}0.009 * \\
(0.004)\end{array}$ \\
\hline Log of Price of Milk & $\begin{array}{r}-0.029 * * * \\
(0.015)\end{array}$ & $\begin{array}{r}0.023 * * \\
(0.010)\end{array}$ & $\begin{array}{r}0.050 * * * \\
(0.030)\end{array}$ & $\begin{array}{r}0.030^{* *} \\
(0.014)\end{array}$ & $\begin{array}{r}-0.027 * * \\
(0.012)\end{array}$ & $\begin{array}{c}-0.030 * \\
(0.012)\end{array}$ & $\begin{array}{r}-0.003 \\
(0.006)\end{array}$ & $\begin{array}{c}-0.020^{*} \\
(0.009)\end{array}$ & $\begin{array}{l}-0.003 \\
(0.006)\end{array}$ & $\begin{array}{c}-0.032 * \\
(0.012)\end{array}$ \\
\hline Log of Price of Meat & $\begin{array}{c}-0.024 * \\
(0.005)\end{array}$ & $\begin{array}{c}-0.009 * \\
(0.004)\end{array}$ & $\begin{array}{r}0.030^{* *} \\
(0.014)\end{array}$ & $\begin{array}{l}0.069 * \\
(0.005)\end{array}$ & $\begin{array}{r}0.012 \\
(0.008)\end{array}$ & $\begin{array}{c}-0.014 * \\
(0.004)\end{array}$ & $\begin{array}{r}-0.006^{*} \\
(0.002)\end{array}$ & $\begin{array}{c}-0.011^{*} \\
(0.003)\end{array}$ & $\begin{array}{c}-0.014 * \\
(0.005)\end{array}$ & $\begin{array}{r}0.010^{* * *} \\
(0.005)\end{array}$ \\
\hline Log of Price of Fruits & $\begin{array}{r}-0.026 * * \\
(0.012)\end{array}$ & $\begin{array}{r}0.005 \\
(0.004)\end{array}$ & $\begin{array}{r}-0.027 * * \\
(0.012)\end{array}$ & $\begin{array}{r}0.012 \\
(0.008)\end{array}$ & $\begin{array}{c}0.073^{*} \\
(0.010)\end{array}$ & $\begin{array}{c}-0.030 * \\
(0.005)\end{array}$ & $\begin{array}{r}-0.000 \\
(0.002)\end{array}$ & $\begin{array}{c}-0.02 * * \\
(0.007)\end{array}$ & $\begin{array}{r}-0.005^{* * *} \\
(0.003)\end{array}$ & $\begin{array}{l}-0.011 \\
(0.009)\end{array}$ \\
\hline Log of Price of Vegetables & $\begin{array}{r}-0.008 \\
(0.006)\end{array}$ & $\begin{array}{c}-0.015^{*} \\
(0.005)\end{array}$ & $\begin{array}{c}-0.030 * \\
(0.012)\end{array}$ & $\begin{array}{c}-0.014 * \\
(0.004)\end{array}$ & $\begin{array}{c}-0.014^{*} \\
(0.004)\end{array}$ & $\begin{array}{c}0.085^{*} \\
(0.006)\end{array}$ & $\begin{array}{r}-0.003 \\
(0.007)\end{array}$ & $\begin{array}{r}-0.008 * * \\
(0.003)\end{array}$ & $\begin{array}{l}-0.004 \\
(0.004)\end{array}$ & $\begin{array}{r}0.006 \\
(0.005)\end{array}$ \\
\hline Log of Price of Pulses & $\begin{array}{r}-0.02 * * * \\
(0.009)\end{array}$ & $\begin{array}{r}0.005 * * \\
(0.002)\end{array}$ & $\begin{array}{r}-0.003 \\
(0.006)\end{array}$ & $\begin{array}{c}-0.006^{*} \\
(0.002)\end{array}$ & $\begin{array}{r}-0.000 \\
(0.002)\end{array}$ & $\begin{array}{r}-0.003 \\
(0.007)\end{array}$ & $\begin{array}{c}0.028^{*} \\
(0.003)\end{array}$ & $\begin{array}{c}-0.004^{*} \\
(0.002)\end{array}$ & $\begin{array}{r}0.002 \\
(0.004)\end{array}$ & $\begin{array}{r}0.001 \\
(0.001)\end{array}$ \\
\hline Log of Price of Oil/Ghee & $\begin{array}{r}0.002 \\
(0.004)\end{array}$ & $\begin{array}{c}-0.010^{*} \\
(0.003)\end{array}$ & $\begin{array}{r}-0.020^{*} \\
(0.009)\end{array}$ & $\begin{array}{r}-0.011 * \\
(0.003)\end{array}$ & $\begin{array}{r}-0.016^{* *} \\
(0.007)\end{array}$ & $\begin{array}{r}-0.008 * * \\
(0.003)\end{array}$ & $\begin{array}{r}-0.004 * \\
(0.002)\end{array}$ & $\begin{array}{l}0.076^{*} \\
(0.003)\end{array}$ & $\begin{array}{r}0.002 \\
(0.004)\end{array}$ & $\begin{array}{r}-0.001 * * \\
(0.000)\end{array}$ \\
\hline Log of Price of Tea & $\begin{array}{l}0.013^{*} \\
(0.005)\end{array}$ & $\begin{array}{r}0.002 \\
(0.003)\end{array}$ & $\begin{array}{r}-0.003 \\
(0.006)\end{array}$ & $\begin{array}{c}-0.014^{*} \\
(0.005)\end{array}$ & $\begin{array}{r}0.005^{* * *} * \\
(0.003)\end{array}$ & $\begin{array}{r}-0.004 \\
(0.004)\end{array}$ & $\begin{array}{r}0.002 \\
(0.004)\end{array}$ & $\begin{array}{r}0.002 \\
(0.004)\end{array}$ & $\begin{array}{l}0.028^{*} \\
(0.002)\end{array}$ & $\begin{array}{r}0.000 \\
(0.001)\end{array}$ \\
\hline Log of Price of Other Food & $\begin{array}{r}0.009 \\
(0.006)\end{array}$ & $\begin{array}{l}0.009^{*} \\
(0.004)\end{array}$ & $\begin{array}{r}-0.032 * \\
(0.012)\end{array}$ & $\begin{array}{r}0.010 * * * \\
(0.005)\end{array}$ & $\begin{array}{r}-0.011 \\
(0.009)\end{array}$ & $\begin{array}{r}0.006 \\
(0.005)\end{array}$ & $\begin{array}{r}0.001 \\
(0.001)\end{array}$ & $\begin{array}{r}-0.001^{* *} \\
(0.000)\end{array}$ & $\begin{array}{r}0.000 \\
(0.001)\end{array}$ & $\begin{array}{l}0.009 * \\
(0.001)\end{array}$ \\
\hline Income (expenditures) & $\begin{array}{c}-0.032 * \\
(0.007)\end{array}$ & $\begin{array}{l}-0.004 \\
(0.005)\end{array}$ & $\begin{array}{c}0.099^{*} \\
(0.013)\end{array}$ & $\begin{array}{c}-0.024^{*} \\
(0.006)\end{array}$ & $\begin{array}{c}0.071^{*} \\
(0.010)\end{array}$ & $\begin{array}{r}-0.012 * * \\
(0.005)\end{array}$ & $\begin{array}{r}-0.042 * \\
(0.002)\end{array}$ & $\begin{array}{r}-0.028^{*} \\
(0.004)\end{array}$ & $\begin{array}{c}-0.027^{*} \\
(0.002)\end{array}$ & $\begin{array}{r}-0.001 * * \\
(0.001)\end{array}$ \\
\hline Household Size & $\begin{array}{c}-0.002 * \\
(0.001)\end{array}$ & $\begin{array}{r}0.000 \\
(0.000)\end{array}$ & $\begin{array}{r}-0.001 \\
(0.002)\end{array}$ & $\begin{array}{r}0.001 \\
(0.000)\end{array}$ & $\begin{array}{l}0.005^{*} \\
(0.002)\end{array}$ & $\begin{array}{r}0.001 \\
(0.001)\end{array}$ & $\begin{array}{r}-0.000 \\
(0.000)\end{array}$ & $\begin{array}{l}-0.001 \\
(0.000)\end{array}$ & $\begin{array}{c}-0.002^{*} \\
(0.000)\end{array}$ & $\begin{array}{r}-0.000 * * \\
(0.000)\end{array}$ \\
\hline Constant & $\begin{array}{l}0.630 * \\
(0.119)\end{array}$ & $\begin{array}{r}0.004 \\
(0.078)\end{array}$ & $\begin{array}{c}0.136^{*} \\
(0.218)\end{array}$ & $\begin{array}{r}-0.116 \\
(0.102)\end{array}$ & $\begin{array}{c}-0.493^{*} \\
(0.176)\end{array}$ & $\begin{array}{c}0.272 * \\
(0.090)\end{array}$ & $\begin{array}{c}0.328^{*} \\
(0.043)\end{array}$ & $\begin{array}{r}0.153^{* *} \\
(0.070)\end{array}$ & $\begin{array}{r}0.082 * * * \\
(0.047)\end{array}$ & $\begin{array}{r}0.004 \\
(0.015)\end{array}$ \\
\hline Observations & 1250 & 1250 & 1250 & 1250 & 1250 & 1250 & 1250 & 1250 & 1250 & 1250 \\
\hline R-Squared & 0.145 & 0.068 & 0.140 & 0.261 & 0.152 & 0.276 & 0.390 & 0.510 & 0.269 & 0.035 \\
\hline Chi & 125.26 & 54.57 & 121.16 & 262.37 & 133.11 & 282.92 & 473.86 & 769.75 & 272. & 177.93 \\
\hline
\end{tabular}

Source: Author's Own estimation with survey data. Standard errors are reported in parentheses.

$*, * *$ and $* * *$ show estimates are statistically significant at 1,5 and $10 \%$ respectively. 
Journal of Applied Economics and Business Studies, Volume.4, Issue 3 (2020) 185-198 https://doi.org/10.34260/jaebs.438

Table-5: Estimated Uncompensated Own and Cross-Price Elasticities of Demand

\begin{tabular}{|c|c|c|c|c|c|c|c|c|c|c|}
\hline Food group & Wheat & Rice & Milk & Meat & Fruit & Vege. & Pulses & Oil/Ghee & Tea & Other Food \\
\hline Wheat & $\begin{array}{l}-0.286 * \\
(0.071)\end{array}$ & $\begin{array}{l}0.186^{*} \\
(0.057)\end{array}$ & $\begin{array}{l}-0.153 * * \\
(0.065)\end{array}$ & $\begin{array}{l}-0.174 * \\
(0.048)\end{array}$ & $\begin{array}{l}-0.042 \\
(0.057)\end{array}$ & $\begin{array}{l}-0.025 \\
(0.065)\end{array}$ & $\begin{array}{l}-0.067 \\
(0.079)\end{array}$ & $\begin{array}{l}-0.082 * * \\
(0.041)\end{array}$ & $\begin{array}{l}0.117 * \\
(0.046)\end{array}$ & $\begin{array}{l}0.100 * * \\
(0.051)\end{array}$ \\
\hline Rice & $\begin{array}{c}0.028 \\
(0.106)\end{array}$ & $\begin{array}{l}-0.649 * \\
(0.086)\end{array}$ & $\begin{array}{l}0.130 \\
(0.190)\end{array}$ & $\begin{array}{l}-0.053 \\
(0.068)\end{array}$ & $\begin{array}{l}-0.054 \\
(0.081)\end{array}$ & $\begin{array}{l}-0.14 * * * \\
(0.075)\end{array}$ & $\begin{array}{l}-0.20 * * * \\
(0.333)\end{array}$ & $\begin{array}{l}-0.17 * * * \\
(0.058)\end{array}$ & $\begin{array}{l}0.147 * * \\
(0.067)\end{array}$ & $\begin{array}{l}0.173 * * \\
(0.075)\end{array}$ \\
\hline Milk & $\begin{array}{l}-0.159 * \\
(0.060)\end{array}$ & $\begin{array}{l}-0.111 * * \\
(0.049)\end{array}$ & $\begin{array}{c}-0.915 * \\
(0.111)\end{array}$ & $\begin{array}{l}-0.160 * \\
(0.043)\end{array}$ & $\begin{array}{l}-0.206^{*} \\
(0.050)\end{array}$ & $\begin{array}{l}0.371 * \\
(0.057)\end{array}$ & $\begin{array}{l}-0.12 * * * \\
(0.066)\end{array}$ & $\begin{array}{l}-0.180 * \\
(0.038)\end{array}$ & $\begin{array}{l}-0.139 * \\
(0.042)\end{array}$ & $\begin{array}{l}-0.222 * \\
(0.046)\end{array}$ \\
\hline Meat & $\begin{array}{l}-0.12 * * * \\
(0.067)\end{array}$ & $\begin{array}{l}0.050 \\
(0.055)\end{array}$ & $\begin{array}{l}0.310 * \\
(0.123)\end{array}$ & $\begin{array}{l}-0.342 * \\
(0.045)\end{array}$ & $\begin{array}{l}0.005 \\
(0.055)\end{array}$ & $\begin{array}{l}-0.046 \\
(0.062)\end{array}$ & $\begin{array}{l}0.11 * * * \\
(0.066)\end{array}$ & $\begin{array}{l}-0.019 \\
(0.039)\end{array}$ & $\begin{array}{l}-0.088 * * \\
(0.045)\end{array}$ & $\begin{array}{l}0.104 * * \\
(0.050)\end{array}$ \\
\hline Fruit & $\begin{array}{l}-0.235^{*} \\
(0.080)\end{array}$ & $\begin{array}{l}-0.127 * * \\
(0.065)\end{array}$ & $\begin{array}{l}-0.22 * * * \\
(0.145)\end{array}$ & $\begin{array}{l}0.002 \\
(0.055)\end{array}$ & $\begin{array}{l}-0.605 * \\
(0.066)\end{array}$ & $\begin{array}{l}0.015 \\
(0.075)\end{array}$ & $\begin{array}{l}0.109 \\
(0.090)\end{array}$ & $\begin{array}{l}0.145^{*} \\
(0.048)\end{array}$ & $\begin{array}{l}0.161 * \\
(0.054)\end{array}$ & $\begin{array}{l}0.119 * * \\
(0.060)\end{array}$ \\
\hline Vegetables & $\begin{array}{l}-0.057 \\
(0.059)\end{array}$ & $\begin{array}{l}0.088 * * \\
(0.040)\end{array}$ & $\begin{array}{l}-0.254 * * \\
(0.112)\end{array}$ & $\begin{array}{l}-0.199 * \\
(0.040)\end{array}$ & $\begin{array}{l}-0.264 * \\
(0.048)\end{array}$ & $\begin{array}{l}-0.208 * \\
(0.055)\end{array}$ & $\begin{array}{l}-0.006 \\
(0.068)\end{array}$ & $\begin{array}{l}-0.066^{* *} \\
(0.034)\end{array}$ & $\begin{array}{l}-0.032 \\
(0.040)\end{array}$ & $\begin{array}{l}0.075 * * * \\
(0.045)\end{array}$ \\
\hline Pulses & $\begin{array}{l}-0.038 \\
(0.072)\end{array}$ & $\begin{array}{l}0.176^{*} \\
(0.059)\end{array}$ & $\begin{array}{l}-0.032 \\
(0.137)\end{array}$ & $\begin{array}{l}0.104 * * \\
(0.048)\end{array}$ & $\begin{array}{l}0.022 \\
(0.058)\end{array}$ & $\begin{array}{l}0.029 \\
(0.067)\end{array}$ & $\begin{array}{l}-0.294 * \\
(0.083)\end{array}$ & $\begin{array}{l}-0.032 \\
(0.042)\end{array}$ & $\begin{array}{l}0.060 \\
(0.049)\end{array}$ & $\begin{array}{l}0.075 * * * \\
(0.044)\end{array}$ \\
\hline Oil/Ghee & $\begin{array}{l}0.053 \\
(0.062)\end{array}$ & $\begin{array}{l}-0.022 \\
(0.050)\end{array}$ & $\begin{array}{l}-0.122 \\
(0.116)\end{array}$ & $\begin{array}{l}-0.112 * \\
(0.042)\end{array}$ & $\begin{array}{l}-0.037 \\
(0.050)\end{array}$ & $\begin{array}{l}0.044 \\
(0.058)\end{array}$ & $\begin{array}{l}-0.058 \\
(0.071)\end{array}$ & $\begin{array}{l}-\mathbf{0 . 0 4} * * * \\
(0.021)\end{array}$ & $\begin{array}{l}0.034 \\
(0.042)\end{array}$ & $\begin{array}{l}-0.015 \\
(0.046)\end{array}$ \\
\hline Tea & $\begin{array}{l}0.246^{*} \\
(0.073)\end{array}$ & $\begin{array}{l}0.079 * * * \\
(0.045)\end{array}$ & $\begin{array}{l}-0.048 \\
(0.139)\end{array}$ & $\begin{array}{l}0.099 * * \\
(0.049)\end{array}$ & $\begin{array}{l}-0.076 \\
(0.059)\end{array}$ & $\begin{array}{l}0.053 \\
(0.068)\end{array}$ & $\begin{array}{l}0.075 \\
(0.085)\end{array}$ & $\begin{array}{l}-0.017 \\
(0.043)\end{array}$ & $\begin{array}{l}-0.351 * \\
(0.049)\end{array}$ & $\begin{array}{l}0.026 \\
(0.055)\end{array}$ \\
\hline Other Food & $\begin{array}{l}0.052 \\
(0.078)\end{array}$ & $\begin{array}{l}-0.070 \\
(0.064)\end{array}$ & $\begin{array}{l}-0.293 * * \\
(0.148)\end{array}$ & $\begin{array}{l}-0.004 \\
(0.053)\end{array}$ & $\begin{array}{l}0.019 \\
(0.064)\end{array}$ & $\begin{array}{l}0.037 \\
(0.073)\end{array}$ & $\begin{array}{l}0.058 \\
(0.091)\end{array}$ & $\begin{array}{l}-0.093 * * \\
(0.045)\end{array}$ & $\begin{array}{l}0.046 \\
(0.053)\end{array}$ & $\begin{array}{c}-0.315 * \\
(0.059)\end{array}$ \\
\hline
\end{tabular}

Source: Author's own calculation based on primary data for the year 2018-19.

$*, * *$ and $* * *$ show estimates are statistically significant at 1,5 and $10 \%$ respectively. 
Ghulam Sadiq Afridi, Muhammad Ishaq \& Abdul Jabbar

Table-6: Estimated Compensated Own and Cross-Price Elasticities of Demand

\begin{tabular}{|c|c|c|c|c|c|c|c|c|c|c|}
\hline Food group & Wheat & Rice & Milk & Meat & Fruit & Veget. & Pulses & Oil/Ghee & Tea & Other Food \\
\hline Wheat & $\begin{array}{l}-0.398 * \\
(0.069)\end{array}$ & $\begin{array}{l}0.117 * * \\
(0.057)\end{array}$ & $\begin{array}{l}0.032 \\
(0.133)\end{array}$ & $\begin{array}{l}-0.086 * * * \\
(0.046)\end{array}$ & $\begin{array}{l}0.047 \\
(0.056)\end{array}$ & $\begin{array}{l}0.099 * * * \\
(0.060)\end{array}$ & $\begin{array}{l}-0.093 \\
(0.081)\end{array}$ & $\begin{array}{l}-0.001 \\
(0.040)\end{array}$ & $\begin{array}{l}0.157 * \\
(0.047)\end{array}$ & $\begin{array}{l}0.094 * * * \\
(0.053)\end{array}$ \\
\hline Rice & $\begin{array}{l}0.088 \\
(0.105)\end{array}$ & $\begin{array}{l}-\mathbf{0 . 6 0 1} * \\
(0.086)\end{array}$ & $\begin{array}{l}0.721 * \\
(0.200)\end{array}$ & $\begin{array}{l}-0.068 \\
(0.071)\end{array}$ & $\begin{array}{l}0.251^{*} \\
(0.085)\end{array}$ & $\begin{array}{l}-0.180 * * \\
(0.088)\end{array}$ & $\begin{array}{l}-0.099 \\
(0.122)\end{array}$ & $\begin{array}{l}-0.113^{* *} \\
(0.055)\end{array}$ & $\begin{array}{l}0.122 * * * \\
(0.071)\end{array}$ & $\begin{array}{l}0.202 * * \\
(0.079)\end{array}$ \\
\hline Milk & $\begin{array}{l}0.060 * * * \\
(0.045)\end{array}$ & $\begin{array}{l}0.040 \\
(0.047)\end{array}$ & $\begin{array}{c}-0.548 * \\
(0.108)\end{array}$ & $\begin{array}{l}0.038 \\
(0.038)\end{array}$ & $\begin{array}{l}0.058 \\
(0.046)\end{array}$ & $\begin{array}{l}-0.169 * \\
(0.053)\end{array}$ & $\begin{array}{l}0.034 \\
(0.066)\end{array}$ & $\begin{array}{l}0.003 \\
(0.033)\end{array}$ & $\begin{array}{l}0.002 \\
(0.039)\end{array}$ & $\begin{array}{l}-0.106 * * \\
(0.043)\end{array}$ \\
\hline Meat & $\begin{array}{l}-0.025 \\
(0.066)\end{array}$ & $\begin{array}{l}0.078 * * * \\
(0.050)\end{array}$ & $\begin{array}{c}0.553^{*} \\
(0.125)\end{array}$ & $\begin{array}{l}-0.258 * \\
(0.044)\end{array}$ & $\begin{array}{l}0.180 * \\
(0.053)\end{array}$ & $\begin{array}{l}0.003 \\
(0.062)\end{array}$ & $\begin{array}{l}0.128 * * * \\
(0.076)\end{array}$ & $\begin{array}{l}0.049 * * * \\
(0.031)\end{array}$ & $\begin{array}{l}-0.082 * * * \\
(0.045)\end{array}$ & $\begin{array}{l}0.107 * * \\
(0.050)\end{array}$ \\
\hline Fruit & $\begin{array}{l}-0.044 \\
(0.078)\end{array}$ & $\begin{array}{l}-0.004 \\
(0.046)\end{array}$ & $\begin{array}{l}0.119 \\
(0.149)\end{array}$ & $\begin{array}{l}0.182 * \\
(0.053)\end{array}$ & $\begin{array}{l}-0.376 * \\
(0.064)\end{array}$ & $\begin{array}{l}0.203 * \\
(0.073)\end{array}$ & $\begin{array}{l}0.010 \\
(0.091)\end{array}$ & $\begin{array}{l}-0.017 \\
(0.045)\end{array}$ & $\begin{array}{l}-0.030 \\
(0.053)\end{array}$ & $\begin{array}{l}-0.056 \\
(0.059)\end{array}$ \\
\hline Vegetables & $\begin{array}{l}0.050 \\
(0.058)\end{array}$ & $\begin{array}{l}0.129 * \\
(0.048)\end{array}$ & $\begin{array}{l}0.002 \\
(0.111)\end{array}$ & $\begin{array}{l}-0.023 \\
(0.039)\end{array}$ & $\begin{array}{l}-0.118^{*} \\
(0.045)\end{array}$ & $\begin{array}{l}-0.111 * * \\
(0.054)\end{array}$ & $\begin{array}{l}0.019 \\
(0.068)\end{array}$ & $\begin{array}{l}0.004 \\
(0.034)\end{array}$ & $\begin{array}{l}0.007 \\
(0.039)\end{array}$ & $\begin{array}{l}0.075^{* * *} \\
(0.044)\end{array}$ \\
\hline Pulses & $\begin{array}{l}0.040 \\
(0.072)\end{array}$ & $\begin{array}{l}0.186^{*} \\
(0.059)\end{array}$ & $\begin{array}{l}0.194 * * * \\
(0.131)\end{array}$ & $\begin{array}{l}-0.037 \\
(0.048)\end{array}$ & $\begin{array}{l}0.138^{*} \\
(0.050)\end{array}$ & $\begin{array}{l}0.097 * * * \\
(0.062)\end{array}$ & $\begin{array}{l}-0.294 * \\
(0.083)\end{array}$ & $\begin{array}{l}-0.017 \\
(0.042)\end{array}$ & $\begin{array}{l}0.055 \\
(0.050)\end{array}$ & $\begin{array}{l}0.036 \\
(0.055)\end{array}$ \\
\hline Oil/Ghee & $\begin{array}{l}0.146 * * \\
(0.060)\end{array}$ & $\begin{array}{l}0.002 \\
(0.050)\end{array}$ & $\begin{array}{l}0.118 \\
(0.116)\end{array}$ & $\begin{array}{l}-0.031 \\
(0.041)\end{array}$ & $\begin{array}{l}0.094 * * \\
(0.043)\end{array}$ & $\begin{array}{l}0.126 * * \\
(0.057)\end{array}$ & $\begin{array}{l}-0.044 \\
(0.071)\end{array}$ & $\begin{array}{l}-0.162 * * * \\
(0.098)\end{array}$ & $\begin{array}{l}-0.018 \\
(0.042)\end{array}$ & $\begin{array}{l}-0.026 \\
(0.046)\end{array}$ \\
\hline Tea & $\begin{array}{l}0.338 * \\
(0.073)\end{array}$ & $\begin{array}{l}0.104 * * * \\
(0.059)\end{array}$ & $\begin{array}{l}-0.193 * * * \\
(0.125)\end{array}$ & $\begin{array}{l}0.181 * \\
(0.049)\end{array}$ & $\begin{array}{l}0.055 \\
(0.059)\end{array}$ & $\begin{array}{l}0.136 * * \\
(0.068)\end{array}$ & $\begin{array}{l}0.089 \\
(0.085)\end{array}$ & $\begin{array}{l}0.037 \\
(0.042)\end{array}$ & $\begin{array}{c}-0.333 * \\
(0.049)\end{array}$ & $\begin{array}{l}0.012 \\
(0.055)\end{array}$ \\
\hline Other Food & $\begin{array}{l}0.064 \\
(0.077)\end{array}$ & $\begin{array}{l}-0.058 \\
(0.064)\end{array}$ & $\begin{array}{l}-0.280 * * \\
(0.148)\end{array}$ & $\begin{array}{l}0.008 \\
(0.053)\end{array}$ & $\begin{array}{l}0.032 \\
(0.063\end{array}$ & $\begin{array}{l}0.049 \\
(0.073)\end{array}$ & $\begin{array}{l}0.071 \\
(0.091)\end{array}$ & $\begin{array}{l}-0.080 * * * \\
(0.045)\end{array}$ & $\begin{array}{l}0.058 \\
(0.053)\end{array}$ & $\begin{array}{c}-0.303^{*} \\
(0.059)\end{array}$ \\
\hline
\end{tabular}

Source: Author's own calculation based on primary data for the year 2018-19.

$*, * *$ and $* * *$ show estimates are statistically significant at 1,5 and $10 \%$ respectively. 
Journal of Applied Economics and Business Studies, Volume.4, Issue 3 (2020) 185-198 https://doi.org/10.34260/jaebs.438

Table-7: Current and Projected Demand of Different Food Groups in AJK

\begin{tabular}{|c|c|c|c|c|c|c|c|c|c|c|c|}
\hline YEAR & Pop (m) & $\begin{array}{l}\text { Wheat } \\
\text { (mt) }\end{array}$ & Rice (mt) & Milk (ml) & Meat (mt) & Fruit (mt) & $\begin{array}{l}\text { Veget. } \\
\text { (mt) }\end{array}$ & Puls (mt) & Oil/ (mt) & Tea $(t)$ & Oth (mt) \\
\hline 2017 & 4.045 & 0.343 & 0.063 & 365.16 & 0.051 & 0.175 & 0.259 & 0.034 & 0.045 & 0.009 & 0.016 \\
\hline 2020 & 4.360 & 0.400 & 0.087 & 538.20 & 0.068 & 0.262 & 0.344 & 0.035 & 0.056 & 0.010 & 0.021 \\
\hline 2025 & 4.781 & 0.485 & 0.097 & 875.99 & 0.094 & 0.436 & 0.489 & 0.038 & 0.075 & 0.012 & 0.030 \\
\hline 2030 & 5.242 & 0.586 & 0.109 & 1425.79 & 0.129 & 0.725 & 0.695 & 0.042 & 0.099 & 0.015 & 0.043 \\
\hline 2035 & 5.748 & 0.709 & 0.123 & 2320.65 & 0.177 & 1.206 & 0.989 & 0.047 & 0.132 & 0.018 & 0.061 \\
\hline 2040 & 6.303 & 0.858 & 0.139 & 3777.17 & 0.244 & 2.007 & 1.406 & 0.051 & 0.176 & 0.022 & 0.086 \\
\hline 2045 & 6.911 & 1.037 & 0.158 & 6147.84 & 0.336 & 3.340 & 2.000 & 0.056 & 0.234 & 0.028 & 0.121 \\
\hline 2050 & 7.588 & 1.255 & 0.179 & 10006.41 & 0.462 & 5.557 & 2.844 & 0.062 & 0.312 & 0.034 & 0.171 \\
\hline
\end{tabular}

Source: Author's own calculation based on primary data for the year 2018-19.

Table-8 (a): Demand and Supply Situation of Different Food Groups in AJK

\begin{tabular}{|c|c|c|c|c|c|c|c|c|c|}
\hline \multirow[t]{2}{*}{ YEAR } & \multicolumn{3}{|c|}{ Wheat $($ million tons) Gr. Rate $=2.3 \%$} & \multicolumn{3}{|c|}{ Rice (million tons) Gr. Rate $=1.3 \%$} & \multicolumn{3}{|c|}{ Fruits (million tons) Gr. Rate $=-\mathbf{0 . 0 0 4 \%}$} \\
\hline & Demand & Supply & Gap & Demand & Supply & Gap & Demand & Supply & Gap \\
\hline 2017 & 0.343 & 0.149 & -0.194 & 0.063 & 0.007 & -0.056 & 0.175 & 0.971 & -0.796 \\
\hline 2020 & 0.400 & 0.160 & -0.240 & 0.087 & 0.007 & -0.080 & 0.262 & 0.936 & -0.675 \\
\hline 2025 & 0.485 & 0.179 & -0.306 & 0.097 & 0.007 & -0.090 & 0.436 & 0.814 & -0.378 \\
\hline 2030 & 0.586 & 0.201 & -0.385 & 0.109 & 0.008 & -0.102 & 0.725 & 0.640 & -0.085 \\
\hline 2035 & 0.709 & 0.225 & -0.484 & 0.123 & 0.008 & -0.115 & 1.206 & 0.455 & -0.751 \\
\hline 2040 & 0.858 & 0.252 & -0.606 & 0.139 & 0.009 & -0.130 & 2.007 & 0.293 & -1.714 \\
\hline 2045 & 1.037 & 0.282 & -0.755 & 0.158 & 0.009 & -0.148 & 3.340 & 0.170 & -3.169 \\
\hline 2050 & 1.255 & 0.316 & -0.939 & 0.179 & 0.010 & -0.169 & 5.557 & 0.090 & -5.467 \\
\hline
\end{tabular}

Source: Author's own calculation based on primary data for the year 2018-19. 
Ghulam Sadiq Afridi, Muhammad Ishaq \& Abdul Jabbar

Table-8 (b): Demand and Supply Situation of Different Food Groups in AJK

\begin{tabular}{|c|c|c|c|c|c|c|c|c|c|}
\hline \multirow{2}{*}{ YEAR } & \multicolumn{3}{|c|}{ Vegetables (million tons) Gr. Rate $=\mathbf{2 . 8 9 \%}$} & \multicolumn{3}{|c|}{ Meat (million tons) Gr. Rate $=1.09 \%$} & \multicolumn{3}{|c|}{ Milk (million liters) Gr. Rate $=1.32 \%$} \\
\hline & Demand & Supply & Gap & Demand & Supply* & Gap & Demand & Supply* & Gap \\
\hline 2017 & 0.259 & 0.020 & -0.240 & 0.051 & 0.087 & +0.036 & 365 & 1024 & +659 \\
\hline 2020 & 0.344 & 0.021 & -0.322 & 0.068 & 0.090 & +0.022 & 538 & 1065 & +526 \\
\hline 2025 & 0.489 & 0.025 & -0.464 & 0.094 & 0.095 & +0.001 & 876 & 1136 & +260 \\
\hline 2030 & 0.695 & 0.029 & -0.666 & 0.129 & 0.100 & -0.029 & 1426 & 1211 & -214 \\
\hline 2035 & 0.989 & 0.033 & -0.956 & 0.177 & 0.106 & -0.072 & 2321 & 1292 & -1028 \\
\hline 2040 & 1.406 & 0.038 & -1.368 & 0.244 & 0.112 & -0.132 & 3777 & 1378 & -2399 \\
\hline 2045 & 2.000 & 0.044 & -1.956 & 0.336 & 0.118 & -0.218 & 6148 & 1470 & -4677 \\
\hline 2050 & 2.844 & 0.051 & -2.793 & 0.462 & 0.125 & -0.337 & 10006 & 1568 & -8438 \\
\hline
\end{tabular}

Source: Author's own calculation based on primary data for the year 2018-19.

* Figures seem exaggerated but based on documented figures of Livestock department (milk=2.77 million liters/day, Meat $=0.087$ million tons/year). 